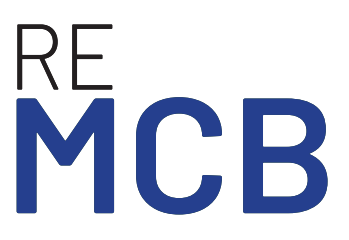

Revista Ecuatoriana de Medicina y Ciencias Biológicas Volumen 42. No. 2, Nov. 2021

\section{The Plant Family Ericaceae ("blueberries") in Ecuador: Ecology, Diversity, Economic Importance, and Conservation}

\author{
La familia de plantas Ericaceae ("mortiños") en Ecuador: Ecología, \\ Diversidad, Importancia económica y Conservación
}

\author{
James L. Luteyn'
}

New York Botanical Garden (Emeritus). Bronx, NY 10458, U.S.A.

*Corresponding author:

jim.luteyn@gmail.com

Recibido 15-09-2021

Aceptado 4-11-2021

DOI: 10.26807/remcb.v42i2.911

e-ISSN 2477-9148

(C) 2021. This paper is published under a CC BY-NC 4.0 license.

\section{Citation:}

Luteyn JL. 2021. The Plant Family

Ericaceae ("blueberries") in Ecuador: Ecology, Diversity, Economic Importance, and Conservation. Revista Ecuatoriana de Medicina y

Ciencias Biológicas 42(2): 79-98. doi: 10.26807/remcb.v42i2.911
Abstract.- Species of the plant family Ericaceae found in Ecuador are generally discussed and characterized as to their diversity, economic importance, conservation, and ecology. Key words: Andes, conservation, endemism, Neotropics, pollination

Resumen.- En el presente trabajo se discuten y caracterizan la diversidad, importancia económica, conservación y ecología de las especies de la familia de plantas Ericáceas de Ecuador.

Palabras clave: Andes, conservación, endemismo Neotrópico, polinización

\section{Introduction}

The plant family Ericaceae, locally known in Ecuador as "familia del mortiño", is one of the key families of vascular plants in the threatened montane forest ecosystem of the Neotropics, where its diversification has been both recent and rapid (Churchill et al. 1995; Luteyn 2002, 2004; Kron \& Luteyn 2005; Schwery et al. 2015). Many species are mycorrhizal and have large, showy flowers with colors in the red and orange range and are pollinated by hummingbirds; however, some species, and even entire genera, have rather inconspicuous flowers of muted colors more suitable for insect pollination (Naskrecki \& Colwell 1998; Luteyn 2002). The fruits are mostly blueblack, juicy berries distributed by birds (Fig. 1); some berries are edible and have potential for commercial cultivation.

\section{Taxonomy}

In Ecuador, the Ericaeae are well represented with approximately 230 species, second only in the Neotropics to Colombia (with approx. 300 spp.) - 131 Ecuadorean species (i.e., 57\%) are endemic or nearly so (Luteyn 1996 and herein updated). Seventeen genera of Ericaceae in Ecuador have inferior ovaries (tribe Vaccinieae; approx. 82\% of the overall species in Ecuador) characterized by berry fruits, the largest genera being Ceratostema (32 species), Psammisia (27 spp.), Macleania (22 spp.), Cavendishia (21 spp.), and Disterigma (23 spp.); Vaccinieae may be terrestrial or epiphytic in their habit. Four genera (approx. 18\% of the species) have superior ovaries and capsular fruits, the largest being Gaultheria (16 spp.) and Bejaria (5 spp.); Pernettya has a berry fruit (see Luteyn 1985, 1995, 1996); all superior-ovary genera are terrestrial in habit. A full taxonomic description for the family and all Ecuadorean species has been provided by Luteyn (1996). For a color-photo field guide to the Ericaceae of Ecuador, see Luteyn 2006. It is felt that many new species are yet to be discovered, principally in the "Oriente".

\section{Ecology, Distribution, and Biogeography}

General Ecology. - In Ecuador, species of Ericaceae are a conspicuous feature in montane cloud forests (between 1700-2500 m elevation), where the soils are well-drained, acidic, and high in organic matter, and where there is sufficient precipitation in the form of fog, mist, or rain; they are not found on the dry side of mountains. In their montane habitats, Ecuadorean Ericaceae are woody subshrubs $0.1-0.2 \mathrm{~m}$ tall, shrubs 1-3 m tall, or rarely trees to $10 \mathrm{~m}$ tall, and terrestrial or epiphytic in habit; some species are lianoid scramblers and at least one case of facultative hemiepiphytism has been documented in Ecuador (Zotz et al. 2021). 

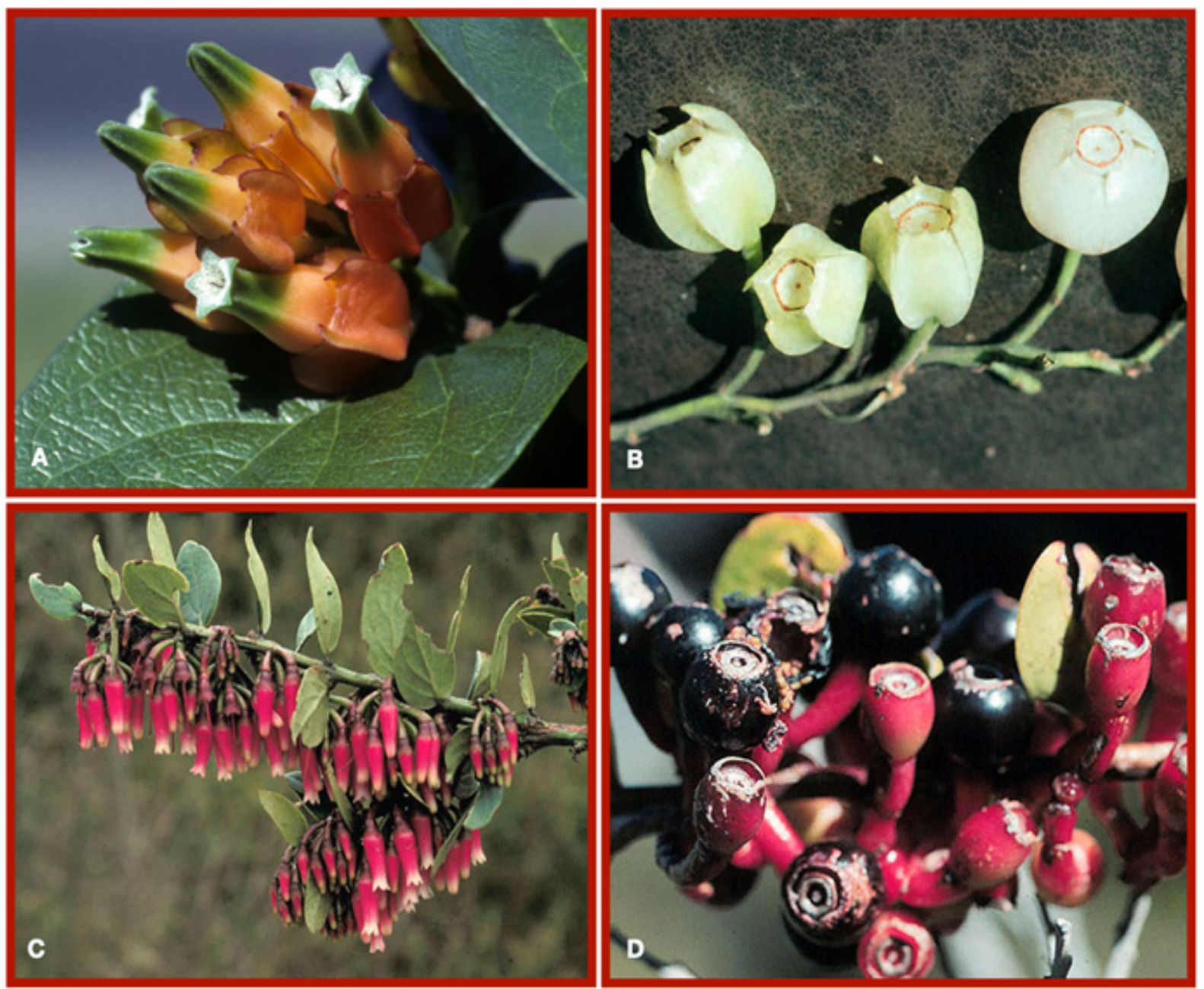

Figure 1. Macleania flowers and fruits. A) M. pentaptera flowers (Ecuador, Luteyn \& Sylva S. 14719, NY); B) M. pentaptera fruits (Ecuador, Luteyn et al. 8026, NY); C) M. rupestis flowers (Ecuador, Luteyn et al. 14118, NY); D) M. rupestris fruits (Costa Rica, Luteyn s.n.). Photos: James L. Luteyn.

While most species are montane, some Ericaceae have adapted to the cooler, but not freezing temperatures of páramo landscapes (3200-4500 m) where they may be creeping subshrubs or even cushion plants. On the opposite side of the spectrum, a few other taxa are found in much warmer habitats as epiphytes in the Pacific-coast mangrove or as lianoid scramblers in lowland rainforests (Smith 1946; Benzing 1987; Luteyn \& Sylva 1994; Luteyn 1999, 2002; Cornejo 2014).

As epiphytes, Ericaceae usually grow in the crotches of larger branches of medium-aged to older trees, not on young twigs or young trees. They have a mutualistic relationship with mycorrhizae. They are anchored to the substrate and are aided in climbing by roots that arise from lignotubers or adventitious roots from moss-covered nodes in very moist sites. These epiphytes receive nutrients and absorb water from host-plant bark runoff or through their roots that penetrate the organic matter and detritus that accumulate around their roots (i.e., non-terrestrial sources). Their relatively large and thick leaves with thick cuticles store water, provide ample surface area to photosynthesize, and slow transpiration during dry and/or windy periods (see Jeník 1971; Gotsch et al. 2015). In low-light or closed-canopy forest situations Ericaceae, whether terrestrial or as epiphytes, can be scandent, and some species are characteristically lianoid scramblers (Luteyn \& Pedraza-Peñalosa 2021). Populations within mature, montane cloud forest, however, are usually epiphytic, often with a few inflorescences and sometimes with large lignotubers for 
storage. Under these low light intensity situations it is difficult for Ericaceae to photosynthesize enough to produce flowers - some may never flower, there not being enough energy reserves for both vegetative growth and flowering (pers. observ.).

In the open subpáramo to páramo regions, Ericaceae tend to be terrestrial, larger in size (or sometimes cushion plants in highly exposed habitats), and often clonal (e.g., Macleania rupestris, Pernettya prostrata, Gaultheria spp., Vaccinium floribundum), frequently containing large numbers of inflorescences and flowers. In these areas, several species in the genera Gaultheria and Pernettya are frequently found as pioneers following volcanic activity or recent landslides, as part of the edge community around mature forests, or in disturbed areas such as clearings after logging or road building, where humans have had great influence. Pioneering populations, however, eventually become overgrown and shaded by other plants, then light is limited and after many years they become weak competitors and do not flower. A particularly abundant species in the páramo, Pernettya prostrata, is resistant to trampling by cattle and is a successional species in heavily grazed areas. This species is especially common in páramo where the vegetation is low and open and persists after the vegetation recovers - fire does not affect it directly, but actually helps spread it indirectly because it opens the vegetation (Pels \& Verweij 1992). Macleania salapa (Loja-N Peru), on the other hand, is fire-resistent due to its large lignotuber that sprouts new growth after fire destroys the main stems (pers. observ.).

Distribution and Biogeography.-The family Ericaceae is clearly Andean-centered and the Ecuadorean species have a close relationship with those of Colombia and Peru. Several species that occur in Ecuador are geographically widespread, such as Cavendishia bracteata (S Mexico to N Bolivia), Macleania rupestris (Costa Rica to N Bolivia), and Sphyrospermum buxifolium (Caribbean and S Mexico to N Bolivia). However, about 57\% of the Ecuadorean species are endemics (or nearly so) with a narrow altitudinal range (Luteyn 2002). Centers of species diversity in Ecuador (based on numbers of species) include: 1) the general northwestern slopes of the Andes (17002500 m elevation); 2) eastern Andean "Oriente", extending from Sucumbíos Prov. south into Peru (900-2500 m elev.); 3) the southern Ecuadorean scrub vegetation (mostly Loja Prov. and into Peru); 4) the high-Andean páramo (3000-3500 m) extending from Colombia throughout the "volcanic belt" of Ecuador; and 5) the low-elevation, Pacific-facing "Chocó biogeographic region" that extends from the Colombia/Ecuador border in Carchi Prov. south into Pichincha Prov. (01000 m) (see Luteyn 2002).

\section{Breeding Systems and Dispersal}

In the Ecuadorean species of Ericaceae there is still a scarcity of information about reproductive systems, pollination biology, and plant/animal interactions; many questions lack hard data and thus remain unanswered.

Asexual Reproduction.-Asexual or vegetative reproduction within Ericaceae in cloud forest, páramo, and boggy habitats, is often accomplished by means of rhizomes or stolons (see Laegaard 1992) and can form large clones and extensive colonies, especially in species such as Pernettya prostrata, Disterigma empetrifolium, and Macleania rupestris, among others. Some species of Ceratostema and Macleania have lignotubers within which there are meristematic zones - these taxa sprout easily after cutting or fire damage (Luteyn 2002). Macleania rupestris is also facultatively lignotuber-producing, probably depending on where the seeds initially land (Sierra \& Mora-Osejo 1994).

Sexual Reproduction.-The flowers of the vast majority of Ericaceae have both staminate and pistillate parts (i.e., flowers perfect), although Sleumer $(1952,1985)$ reported dioecism for Pernettya howellii (endemic to the Galápagos Islands) and Middleton (1991) reported gynodioecism for Pernettya prostrata from Ecuador. Their pollen is already mature and sometimes shed within the bud. Slight tapping of the pendent or horizontally oriented flowers often produces a shower of pollen onto the stigma. The stigma appears receptive quite soon after flowers open, as evidenced by the appearance of a small viscid droplet on the stigma. Although most Ecuadorean Ericaceae pollination syndromes point toward cross-pollination, species such as Bejaria resinosa, Pernettya prostrata, and several Gaultheria are self-compatible 
(Melampy 1987; Luteyn 1995; Kraemer 2001). The fact that several high-elevation species with high flower densities, such as Pernettya prostrata, Gaultheria spp., Cavendishia bracteata, Macleania rupestris, and Thibaudia floribunda, always produce abundant fruit leads me to hypothesize that some species are facultatively self-compatible (Luteyn 2002, but see also Baker 1974; Jacquemart 2003; Chamorro \& Nates-Parra 2015). In fact, in environments where pollinators are more scarce (disturbed/regenerating areas) or in cold/wet páramos, species such as Macleania rupestris may benefit by having the option of multiple reproductive strategies (Navarro et al. 2007). In Ecuador I suspect that the small white flowers of Vaccinium floribundum, Disterigma spp., Pernettya prostrata, and Gaultheria spp., are self-compatible and most likely pollinated by European honeybees (Apis mellifera). However, the study of Navarro et al. (2007) showed that the Ecuadorean Disterigma stereophyllum, with small white flowers, has a mixed pollination syndrome, i.e., it prefers hummingbird pollination (outcrossing) and also profits from small bee visitors, but still maintains the option of autonomous self-pollination. Although no data are available concerning compatibility in the majority of Ecuadorean species of Ericaceae, Luteyn (2002) predicted and Navarro $(1999,2001)$ and Navarro et al. $(2007,2008)$ proved selfcompatibility in Macleania bullata, Macleania rupestris, and Disterigma stereophyllum. Navarro (2001) stated that in Macleania bullata pollinator visits are required for reproduction.

In Ecuadorean Ericaceae, most plants depend on animals for pollination and seed dispersal with rewards of nectar, pollen and/or nutritious fruit. The long-tubular corollas of many Ecuadorean Ericaceae (tribe Vaccinieae) contain a large volume of high energy nectar that provides that reward and also helps to guard the nectar from non-pollinators. The red to orange colors of many Ericaceae flowers also provide a visual and/or contrasting display against the foliage for the birds and at the same time act again as a nectar guard since these floral colors are relatively invisible to insects (Raven 1972; Heinrich 1981). Ericaceae flowers obligately pollinated by hummingbirds may also support a variety of non-pollinating nectar-eating organisms including various "nectar robbers" such as birds, bees, ants, butterflies, mites, bats, bacteria, protozoans, and yeasts (see also Colwell 1973). However, organisms other than birds probably only rarely contact the reproductive parts of the flowers and although they may carry pollen between flowers, the quantities must be very small, so in effect, they do not add much as pollinators.

Flowers of Ecuadorean species of Ericaceae are of major importance to birds in montane regions, not only as pollinators but as fruit dispersers. "If one considers numbers of flowers, ... the Ericaceae is easily the most important family..." (Stiles 1985). Parada-Quintero et al. (2012) stated that "Shrubs and species of Ericaceae were the most important elements ... throughout the year" [in central Colombia]. Ecuadorean species of Ericaceae display the floral traits commonly associated with plants adapted for pollination by hummingbirds, i.e., bird-pollination or "ornithophily" (Table 1).

Dispersal.- Nearly all Ecuadorean Ericaceae attract animal dispersers, especially birds, by means of certain fruit characters, i.e., a bird dispersal syndrome or strategy (see Table 2 and also Snow 1971; van der Pijl 1972; Denslow \& Moermond 1985). Normally, Ecuadorean Ericaceae display large numbers of small, brightly-colored, fleshy, high carbohydrate/low lipid, accessible fruits with numerous, small seeds and a high pulp vs. seed ratio (i.e., nutrition). Vaccinieae especially are of great importance as sources of food for opportunists (herein defined as animals that take advantage of whatever food is available at any given time) with their brightly-colored flowers (pendant for hummingbird foraging and pollination) and many-seeded berry fruits (presented erect for foraging and dispersing frugivores), and they meet most of the fruit criteria for ornithochory listed in Table 2 [Psammisia fruits are the only exception known, having a green, tough outer pericarp and dry inner pulp (pers. observ.)].

Seed dispersal in Ecuadorean Vaccinieae is primarily of two types-autochory and zoochory. Autochory is the mechanism in which plants carry out dispersal of fruits and seeds by themselves, which occurs when, after falling to the ground, the sticky (viscous) mucilaginous sheath that encloses the seeds attaches them to the ground, where they cannot move any further-it is present in several species of Macleania. The second type of dispersal in Ericaceae is called zoochory of which dispersal via ingestion (endozoochory) followed by regurgitation or defecation is the most frequent type. In Ecuador, I have also observed ant-mediated seed 
Table 1. Characters of ornithophily in Ericaceae seen as adaptations for hummingbird pollination (modified from Proctor \& Yeo 1973; Faegri \& van der Pijl 1979; Luteyn \& Sylva 1999).

\begin{tabular}{|l|}
\hline -cool, moist, montane habitats; sun-loving terrestrial and epiphytic lifestyles \\
\hline $\begin{array}{l}\text {-inflorescences with numerous hanging flowers exhibiting negative angles with respect to the horizontal, facing } \\
\text { outward, often opening for a long time; held away from the rest of the plant to ease access by hoverers }\end{array}$ \\
\hline -flowers odorless \\
\hline $\begin{array}{l}\text {-flowers often with presence of "parrot colors," i.e., brightly colored, often in the red and orange range, often } \\
\text { with contrasting colors in different parts of the inflorescence }\end{array}$ \\
\hline \begin{tabular}{l} 
a lip on which insects can land \\
\hline -style usually equaling corolla length with receptive stigma and pollen load located at the mouth of the corolla \\
tube so that the bird must come into contact with each when foraging
\end{tabular} \\
\hline $\begin{array}{l}\text {-anthers rigid, attached to the outside of the nectariferous disk, forming a tunnel leading to the nectar source; } \\
\text { dehiscence introrse }\end{array}$ \\
\hline $\begin{array}{l}\text {-pollen located at bottom of long, tubular-adorned anthers, the theca of which are granular and need to be } \\
\text { moved to effect pollen discharge; pollen dry, loose }\end{array}$ \\
\hline -ovary inferior, the numerous ovules mechanically protected by and separated from the nectar source \\
\hline -nectariferous disc located at base of corolla, fleshy \\
\hline -nectar abundant, diluted, rich in sucrose with average sucrose equivalence $20.4 \%$ and highsucrose:hexose ratio \\
\hline
\end{tabular}

dispersal-myrmecochory — in Cavendishia lebronae, where numerous small, black ants cleaned the seeds of their juicy pulp and then transported the seeds into the undergrowth - I presume to their nests. Ants do this to make "stores" or "caches" for feeding of the young, or possibly for their ant gardens; theoretically, any uneaten seeds would germinate some distance away from the parent plant. Within the superior-ovary genera such as Gaultheria and Pernettya seed dispersal is similar to the Vaccinieae (pers. observ.).

\section{Interactions with Animals}

In the following paragraphs I discuss avian and non-avian animal species that interact in some way with species of Ecuadorean Ericaceae.

Birds. - In Ecuador, hummingbirds are the most frequent pollinators of Ericaceae species with colorful (red to orange), long-tubular flowers, including tubular species of the superior-ovary genus Bejaria (Melampy 1987; Navarro 1999, 2001; Luteyn 2002 and pers. observ.; Navarro et al. 2007, 2008, but see also Kraemer 2001). Hummingbirds hover continuously while searching for food. They are guided to the nectar at the base of the flowers by the narrow, tubular corolla with constricted throats, where they drink nectar as a food source and in so doing touch the stamens dislodging pollen and causing it to fall downward onto the hummingbird's body onto surfaces that brush against the stigmas as the bird probes for nectar. The pollen is then physically transported to the next flower to be visited effecting pollination (Table 2).

Birds are also the most common nectar-robbers of Ericaceae. Nectar-robbing birds or flowerpiercers ("pinchaflores," "robamieles," "robadores de néctar") are not adapted to the elongated flower morphology of many Vaccinieae. Therefore, legitimate nectar-robbers pierce floral tissues near the base of the corolla to extract nectar. Illegitimate nectar-robbers, also called thieves (e.g., ants, mites), obtain nectar after entering the flower through prior-made holes or through the same natural openings used by legitimate pollinators. Thus, in so doing, both types of robbers generally circumvent the anthers and stigma, i.e., they remove floral resources without pollinating (Inouye 1980, 1983; Bronstein et al. 2006; Torres et al. 2008; Irwin et al. 2010). In Navarro et al's $(2007,2008)$ study of Disterigma stereophyllum, they found that "when the robber [Diglossa albilatera] forcefully shook the flower, this caused some release of pollen from the poricidal anthers, most of which fell to the ground, but some adhered to stigmas within the 
Table 2. Adaptive ornithochorous characters seen in the plants and fruits of Ericaceae (including modifications from Snow 1971, van der Pijl 1972, and Denslow \& Moermond 1985).

\begin{tabular}{|l|}
\hline - "in secondary or open vegetation fruits with many small seeds are the rule, since a premium is set on efficient \\
dispersal to take advantage of the many spaces available” (Snow 1971) \\
\hline - plant with most abundant, accessible, and attractive fruits have selective advantage \\
\hline - high visibility due to contrasting colors of fruit (often red, orange, white, blue/black) with \\
accessory structures (red pedicels) and surrounding vegetation \\
\hline - "ripeness signaled by change in color, carbohydrate content, and succulence” (Denslow \& \\
Moermond 1985) \\
\hline -absence of a hard outer cover (i.e., no closed or hard rind) \\
\hline -no smell ("birds have only a weak sense of smell, or none at all, and are purely visual animals" (van der Pijl \\
1972 ) \\
\hline -fleshy, nutrient-rich, edible pulp \\
\hline -small sizes of fruits and seeds \\
\hline -outer protection against being eaten prematurely (acids or tannins present in the immature fruit) \\
\hline -inner protection of the seed against damage in digestive tract (bitterness, hardness, presence of toxic \\
compounds) \\
\hline -semi-permanent attachment to pedicel until physical removal by frugivore \\
\hline -occupy no special position on the plant (ex., not on long-pendent peduncles) \\
\hline
\end{tabular}

pierced flowers." Nectar robbing is common in neotropical Ericaceae and Rojas-Nossa et al. (2016, in Colombia) also found nectar robbing in the Ecuadorean species Bejaria resinosa, Cavendishia bracteata, Gaultheria erecta, G. lanigera, Gaylussacia buxifolia, Macleania rupestris, Pernettya prostrata, Thibaudia floribunda, and Vaccinium floribundum.

Birds and to a much lesser extent mammals that eat fruits (i.e., frugivores) are the most important seed dispersers of Ericaceae. It is the pulp of the fruits that is normally eaten and digested by these frugivores. Seeds are generally regurgitated or defecated soon after being eaten, but remain viable and their germination rate may increase or decrease by passage through the digestive tract of the disperser (see for example, Traveset 1998; Herrera 2002; Ortiz \& Umba 2010; Luteyn pers. observ.).

Bees.- In Ecuadorean Ericaceae, European honeybees ("abejas") act as the primary pollinators of short-tubular or urceolate, white-flower species of the genera Gaultheria, Pernettya, Agarista, and Vaccinium; whereas, large bees (Bombus) are common pollinators of the long-tubular, redflowered species of Bejaria (Clemants 1995; Melampy 1987; Navarro et al. 2007, 2008; Luteyn pers. observ., but see also Freitas et al. 2006). In the long-tubular flowers of the inferior-ovary Vaccinieae, bumblebees (Bombus spp.) along with carpenter bees, wasps, and ants commonly act as nectar-robbers; whether pollinators or nectar-robbers bees are usually foraging for nectar not pollen (Inouye 1983; Heinrich 1983; Irwin et al. 2010). Instead of hovering in front of a flower (as hummingbirds do), bees grasp the hanging flowers with their mandibles and shake the pollen out of the tubular anthers while probing for nectar (see Heinrich 1976).

Ants.-From field observations, ants do not appear to be pollinators, nor are they myrmecophilous, but rather are more likely nectar thieves, protectors from herbivores of young leaves or other plant parts that secrete nectar, secondary dispersers, or harvesters (see Blüthgen et al. 2000; Beattie and Hughes 2002; Bronstein et al. 2006). Interactions observed in Ecuadorean Ericaceae are seemingly based on resources provided by the plants, i.e., nectar, fruits, or seeds, three examples being: Luteyn (1979) observed ants that cleaned seeds from fruit pulp of Cavendishia lebronae and then dispersed those seeds or possibly ate them; Luteyn (1981) also reported leaves and immature fruits of Cavensishia colombiana eaten by a black, fungus ant Acromyrmex hystrix in a fashion similar to leaf-cutter ants, and ants eating leaves of C. palustris; and Luteyn (1983) also observed aggressive red biting ants (genus unknown) present on badly damaged leaves of several species of Vaccinieae (C. tenella, C. angustifolia, C. micayensis, C. palustris, and Macleania stricta) growing together in a decaying tree trunk. Other interactions with ants 
include nesting sites, for example: Luteyn and Wilbur (1977) reported that the root system of Disterigma utleyorum (Costa Rica-Ecuador) was associated with colonies of ants and in which the ants aggressively defended their home environment by painful bites. Pedraza-Peñalosa (2010 and pers. comm.) confirmed seeing plants of D. utleyorum in Ecuador defended by ants of the subfamilies Dolichoderinae and Formicinae, and also Luteyn (1979) noted that the pith region of mature stems of Ceratostema megabracteatum (endemic to Ecuador) became hollow with age and provided a home for tiny, black, non-biting ants.

Miscellaneous Insects. - In general, many insect larvae cause floral damage in Ericaceae and thereby interfere with seed production; they probably also drink nectar which reduces its reward to pollinators. Their presence is usually noted by debris within flowers including their own fecal material and exit holes in fruits and pedicels. Navarro's (2001) study of Macleania bullata noted that rotted flowers contained beetle larvae (Curculionidae). I have also observed maggotlike larvae feeding on flowers and ovaries of Macleania rupestris and leaving exit holes. Larval damage of the micromoth Caloptilia camaronae (Gracillariidae) has been observed infecting Macleania rupestris in Colombia (Arévalo 2014). Wasps may act as nectar robbers in the corolla tubes of Macleania rupestris (G. Weber, pers. comm. 2019). Butterflies and moths have long enough tongues to forage in the long corollas of some Ecuadorean Vaccinieae and are probably mostly nectar-robbers. Navarro (1999, 2001, pers. comm.) noted the butterfly Pronophila orcus as a primary nectar robber on Macleania bullata along the Ecuador border with Colombia. The "Western Flower Thrip" (Frankliniella occidentalis), the "Treehopper" (Ennya sp.), "weevils" (Curculionidae), and "true bugs" (Hemiptera) have all been observed visiting Macleania rupestris in Colombia (J.-L. Combita, pers. comm. 2019). "Leaf miners" (Diptera, Lepidoptera, Coleoptera, and Hymenoptera) also visit Macleania rupestris in Colombia (Arévalo 2014).

Arachnids.-Mites of the family Ascidae depend upon Ericaceae flowers not only as their source of food (nectar and pollen), shelter, and a place for reproduction, but also upon the birds themselves, because their primary means of dispersal from flower to flower is on the bills and in the nasal cavities of hummingbirds (Colwell 1985; Colwell \& Naeem 1994) —an ideal example of a three-way mutualistic relationship! Hummingbird-flower mites may also be classified as nectar thieves (Colwell et al. 1974) — they are not parasitic —, but given their abundance they are likely to be significant competitors with hummingbirds (Colwell 1995). Naskrecki and Colwell (1998) determined that Rhinoesus mites were quite conservative with regard to host plant genera and families, and that with but a single exception, "every species in the genus Rhinoseius for which host plant records exist has been collected from plants of the family Ericaceae. In contrast, none of the [mite] species of the genus Tropicoseius is known from ericads, except for a single specimen of T. steini collected from Ceratostema peruvianum." My own personal observations in the laboratory over nearly 50 years have demonstrated that mites of the genus Rhinoseius inhabit nearly every flower of Vaccinieae dissected and that their presence in the flowers of dried herbarium specimens, such as in Macleania coccoloboides (Ecuador, Luteyn 8474, NY), is indirect proof of hummingbird visitation and subsequent pollination.

Mammals.-The herbivorous rodent known as "guanta de páramo" in Ecuador (Cuniculus taczanowskii (the Mountain Paca, Colombia-Bolivia) eats mostly fruits and seeds. In Colombia its diet includes the fruits of Ericaceae such as Gaultheria erecta, Thibaudia floribunda, and Macleania rupestris (Osbahr et al. 2007), species also represented in Ecuador. The Andean bear, better known as "oso de anteojos" (Tremarctos ornatus; spectacled bear), is an endangered forest and páramo dispersal agent (Panama-Bolivia) that eats primarily plant leaves, fruits and small animals (i.e., omnivore). It purportedly eats berries of Gaultheria, Pernettya prostrata, Cavendishia bracteata, Macleania rupestris, and Vaccinium floribundum (Hernani-Lineros et al. 2020).

\section{Fungal Interactions}

Fungal visitors with Ericaceae may be divided into two groups-phytopathogenic and mycorrhizal fungi.

Phytopathogens. - Studies of phytopathogens of Ericaceae are scarce, but studies from Colombia, which share many Ericaceae species with Ecuador, found necrotic lesions ("manchas") 
on the leaves, flowers, and fruits of Macleania rupestris caused by the fungal pathogens Pestalotia, Cladosporium, Alternaria, Stemphylium, and Gloeosporium, as well as cotton-like ("algodonoso") mycelia, brown lesions, and white pulverulent ("pulvurento") mycelia of Gloeosporium and Cladosporium which covered flowers and fruits; these pathogens affected the normal growth, development, and fruit production of the plant (Gutiérrez 1991). Romero and Sánchez-Nieves (2004) found 12 genera of pathogenic and saprophytic fungi associated with Macleania rupestris, viz., Absidia, Alternaria, Ascochyta, Aspergillus, Cladosporium, Fusarium, Mucor, Nigrospora, Pestalotia, Stemphylium, Thielaviopsis, and Trichoderma. In Peru, Oblitas (2012) observed leaf lessions in cultivated Macleania rupestris that were produced by species of Colletotrichum and Gloeosporium.

Mycorrhizae.-Ericaceae depend strongly on mycorrhizal fungi for nutrient acquisition from soil organic matter and are viewed as a key adaptation that enables Ericaceae to survive and dominate in nutrient poor soils (Read et al. 2004; Vohník et al. 2012); however, mycorrhizae have rarely been studied in tropical regions. Early studies of Ecuadorean fungi by Bermudes and Benzing (1989) demonstrated "fungal associations" in epiphytic roots of Macleania cordifolia. It has also recently been shown that the tribe Vaccinieae is seemingly characterized by a group of ectendomycorrhizae, named "cavendishioid" mycorrhizae, because they were discovered in Cavendishia nobilis var. capitata from southern Ecuador (Setaro et al. 2006, 2013; Brundrett \& Tedersoo 2018) and that the dominant mycobiont belongs to the Sebacinales (Kottke et al. 2008, 2013; Selosse et al. 2007; Setaro \& Kron 2011). Cavendishioid ectendomycorrhizae associations have been also reported in other Cavendishia, Ceratostema, Diogenesia, Disterigma, Macleania, Orthaea, Psammisia, Semiramisia, Sphyrospermum and Thibaudia (Brundrett 2008).

\section{Hybridization}

Hybridization in Ecuadorean Ericaceae under natural conditions is rare, although Middleton $(1989,1990,1991)$ and Luteyn (1995 and pers. observ.) reported intergeneric hybridization events between Pernettya and Gaultheria, and infrageneric hybridization in Gaultheria. Several species of Macleania, such as M. bullata, M. floribunda, and M. stricta, do hybridize under greenhouse conditions (J.R. Ballington, pers. comm. 1993).

\section{Ethnobotany}

Naranjo (1994), stated he believed that at the time of the Spanish conquest in the 15th-Century, Macleania floribunda ("gualicón", "joyapa") was one of the species cultivated for its fruits within the interandean region. Currently, Macleania rupestris ("joyapa", "zagalita", amongst other names) may be purchased in some larger supermarkets, where they are found as fresh or dried fruits, jams or marmalades, or as nectar drinks or wine (Sælemyr 2004; Van den Eynden \& Cueva 2008). Vaccinium floribundum ("mortiño") is most commonly known in the traditional "colada morada" or "mazamorra morada" prepared with "guaguas de pan" (or "t'anta wawa" bread that has the shape of a doll) and consumed every year on November 2"All Souls' Day" or "Día de los Difuntos."

Traditional Uses - Species of Ericaceae have a long history of use by indigenous Ecuadoreans and the large number of common names given to them give credence to the fact that numerous species have been and are currently used locally. Although understudied, ethnobotanical observations confirm culinary, cultural, and medicinal uses of several species. A comprehensive review of the useful species of Ericaceae are contained in the "Enciclopedia de las plantas útiles del Ecuador," where the editors reported that 65 of the approx. 225 species of Ericaceae in Ecuador that they listed had a use (Torre et al. 2008: tabla 1 and pp. 311-316; see also Van den Eynden \& Cueva 2008: table 1). A summary of which (with specific references, and where known species and common names) is given below:

Edible fruits: See Popenoe 1924 (Ceratostema alatum "pera silvestre", "manzanilla"; Disterigma alaternoides "tira"; Disterigma empetrifolium "chirimote"; Macleania rupestris "hualicón", "chaquiIulii", "joyapa", "salapa"; Vaccinium floribundum "mortiño"); Cordero 1950 (Ceratostema peruvianum and other spp. "joyapa", "hualicón"; Macleania floribunda "joyapa"; Vaccinium floribundum "mortiño"); CESA 1992 (Macleania floribunda, M. rupestris); Cerón 1993 (Disterigma acuminatum "gualicón"; Macleania cordifolia, M. loeseneriana, and M. rupestris all "gualicón"; Psammisia 
graebneriana "gualicón de árbol"); Cerón 2002a (Cavendishia bracteata "zagalita"; Disterigma acuminatum "sarsal", D. empetrifolium "chirimote"; Gaultheria glomerata "chigunda"; Macleania loeseneriana "gualicón"; Thibaudia floribunda "gualicón"); Cerón 2002b (Cavendishia tarapotana "cuyac"; Disterigma acuminatum "mortińo", "tirag"; Macleania cf. loeseneriana "gualicón", M. rupestris "cuya"; Psammisia sclerantha "gualicón" all as "alimento").

Toxic fruits: See Cordero 1950 (Pernettya prostrata "taruga joyapa", "tirag"); Luteyn 1995 (Pernettya prostrata); Cerón 2002a (Pernettya prostrata "moridera"); Kvist \& Alarcón S. 2008 (species not given).

Wood as firewood and for woodworking: See Cerón 1993 (Cavendishia bracteata "zagalita"); Cerón 2002a (Thibaudia floribunda "gualicón"); CESA 1992 (Macleania floribunda, M. rupestris); Clemants 1995 (Bejaria). Ellemann (1991) listed useful woods, but did not give more specific uses, for the following species: Bejaria aestuans "payama", Gaultheria erecta "mote pelado", Macleania rupestris "joyapa", and Pernettya prostrata"payanchillo de cerro."

Medicinals: Cordero (1950) mentioned that from Bejaria resinosa (and other spp. of Bejaria) a decoction was made from "aserraduras of polvo del tronco o de la raíz" for people suffering from liver or intestinal diseases. For Macleania rupestris the leaves were made into a drink that accelerated labor ("parto") and reduced labor pains (CESA 1992; Abril 2015). Cerón et al. (2004) found that in Macleania pentaptera the entire plant was macerated and applied on the forehead as a plaster, then in steam baths and as a drink to eliminate cholesterol, fainting attacks, and severe headaches. The Cayapa Indians use Macleania smithiana medicinally as a cure for poisonous and non-poisonous snake bites (see Luteyn 1996; Cornejo 2014). Tene et al. (2007) found that an aqueous infusion of the fresh, mature leaves of Macleania rupestris was drunk as a tonic, while Rios et al. (2007) stated that Macleania rupestris was drunk in a decoction of the flowers to treat nerves.

For other, more general but less specific, cultural and medicinal uses of Ecuadorean Ericaceae, including cooking, see Muñoz (2004), Bussmann and Sharon (2006), Rios et al. (2007), Reyna Achi (2012), Moncayo (2014), Abril (2015), and Gallardo de la Puente (2015).

Horticultural and Ornamental Uses.-Many species of Cavendishia, Ceratostema, Disterigma, Macleania, Psammisia, and Vaccinium have potential as new floricultural crop plants, some being highly ornamental with large, dark green, evergreen leaves and large, brightly colored flowers (Ballington et al. 1993; photos in Luteyn 1996). Although Torre et al. (2008) reported that in Ecuador no native species were known to be used as ornamentals, Cerón (2002a,b) reported that both Cavendishia tarapotana ("orquidea", "cuyac") and Macleania loeseneriana ("gualicón") were used as both "ornamento" and "alimento."

Medicinal Uses.-A few Ecuadorean species of Ericaceae have been investigated for their antioxidant compounds, including Anthopterus wardii, Cavendishia grandifolia, Cav. isernii, Ceratostema silvicola, Disterigma rimbachii, Macleania coccoloboides, M. cordifolia, M. rupestris, and Sphyrospermum buxifolium - they are high in natural antioxidants and have been called "superfruits" because of their bioactive properties and high levels of antioxidant compounds (NRC 1989; Ballington et al. 1990; Cardozo et al. 2009; Dastmalchi et al. 2011; Flores et al. 2012). These antioxidant compounds, such as phenolics (polyphenols, flavonoids, and tannins), fruit colorants (anthocyanins and carotenoids), vitamins (ascorbic acid), and minerals play a fundamental role in preventing chronic and degenerative diseases. Some of these neotropical blueberries, demonstrated significantly stronger antioxidant activities than North American highbush blueberry Vaccinium corymbosum (Flores et al. 2012; Ma et al. 2013; Debnath \& Goyali 2020). For other recent articles about the chemical composition and antioxidant activity of the Andean Vaccinium floribundum, see Vasco et al. (2009), Schreckinger et al. (2010), Ortiz et al. (2013), Prencipe et al. (2014), Alarcón-Barrera et al. (2018), and Llivisaca et al. (2018).

Nutritional Uses.-Within the last two decades major efforts are underway in Colombia and Ecuador to produce new, small-fruit crops from native (wild) species from the Andean regions, 
namely Cavendishia bracteata ("uva de anís"), Macleania rupestris ("joyapa", "gualicón"), and Vaccinium floribundum ("mortiño"), all three also native to Ecuador (see Ligaretto 2009). In all propagation studies of Macleania rupestris and Vaccinium floribundum, propagation by cuttings is recommended (Brand-Prada 1994; Acero \& Bernal 2003; Boni Duchitanga 2016). Although the plants are readily accessible to small producers and the cost is low, the absence of an adequate propagation protocol is still one of the difficulties in their introduction for commercial cultivation (Durán-Casas et al. 2013; Veloza-Suan et al. 2014). For further discussion of the cultivation of wild Andean species, see Torres et al. (2009) and Debnath and Goyali (2020).

\section{Land Use, Restoration Ecology, and Conservation}

Hofstede et al. (2002) and Quiroz Dahiket al. (2019) have demonstrated in Ecuadorean subpáramo and páramo areas where species of Ericaceae are represented, that pine plantations (Pinus patula), intensity of grazing by cattle, and the frequency of burning were all factors in lowering species richness when compared with natural grassland vegetation, thus highlighting the importance of controlling these activities so commonly practiced in the Ecuadorean Andes. Therefore, the several native species of Ericaceae that act as pioneers are increasingly seen as beneficial species for land use, restoration ecology, and vegetation regeneration purposes, especially in areas of anthropogenic disturbance, where biodiversity loss is creating serious problems (see Rodríguez \& Peña 1984; DAMA 2000; Zuluaga \& Espinosa 2005; Montenegro \& Vargas 2008; Torre et al. 2008; Cardozo et al. 2009; Álvarez \& Contreras 2012). Añazco (2008), for example, mentioned six species of Ericaceae, native to Ecuador, that are of major importance in regeneration after forest fires-Bejaria aestuans ("joyapa") and B. resinosa ("payana"), Gaultheria erecta and G. reticulata ("mote pelado"), Macleania salapa ("joyapa blanca"), and Vaccinium floribundum ("mortiño"). Fadaei (2019) also pointed to the importance of reclamation with ericaceous shrubs, because they add beneficial mycorrhizal fungi to the soils. Studies that have also shown the importance of Ericaceae in the overall maintenance of avian biodiversity include the following. In the Andes of eastern Ecuador, Nieto and Silva (2012) studied the influence of timber extraction, grazing, burning, and alien plant species in Ericaceae-dominated, shrubby vegetation areas, where only a few remnants of original vegetation remained and how that habitat alteration affected hummingbird usage of floristic resources (i.e., nectar). There, six species of Ericaceae proved to be the most visited species during their flowering periods and the most important plant resources for the hummingbirds in the secondary forest. In another study in the Colombian Andes, Ortiz and Umba (2010) have shown that Ericaceae are the principal plant family in the diet of frugivorous birds throughout the year and that they are responsible for Ericaceae dispersal.

As seen throughout this paper, several species of Ecuadorean Ericaceae are among the most widespread and ubiquitous neotropical Ericaceae and some may even act as pioneers in areas of natural or man-made disturbance. However, others are rare in nature and poorly known or scarcely collected. Approximately 57\% of Ecuadorean Ericaceae are endemic (occur only in Ecuador) or nearly so (i.e., in close proximity in two adjacent countries). Many of these species have restricted distributional ranges and are known from very few specimens, about 51\% are known from fewer than 10 collections (Luteyn 1996 and unpubl. data). These and others often grow in areas with deteriorating environmental conditions and increasing human pressure. Therefore, it is imperative that better land-use practices and conservation efforts are undertaken to protect these and other species.

The Tropical Andes biogeographic region is the most species rich and ecologically threatened region on Earth and montane ecosystems like the cloud forests, where Ericaceae abound, are today reduced to $10 \%$ of their original extent, mostly due to destructive human activities such as burning, deforestation, road-building, and introduction of domestic livestock (Henderson et al. 1991; Chaves \& Arango 1998; Mast et al. 1999; Hamilton 2001; Orme et al. 2005; United States Agency for International Development 2009). According to Pedraza-Peñalosa et al. (2011) and Luteyn and Pedraza-Peñalosa (2013) "89\% of the Ericaceae endemic to Ecuador have some level of threat."Therefore, many of the Ecuadorean Ericaceae are endangered.

In summary, Andean montane ecosystems are home to about $80 \%$ of the different neotropical Ericaceae species. For this reason, reforestation programs are needed, taking into account that some native Ericaceae are successful colonizers of natural or anthropogenically disturbed areas, 
while others are threatened by habitat loss and are on the verge of extinction (see Durán-Casas et al. 2013). Thus, conservation of native vegetation, including ericaceous-rich habitats especially in montane elevations, must be undertaken in order to sustain species diversity of both plants and animals. Valencia et al. (2000), León-Yánez et al. (2011), and Luteyn and Pedraza (2013) have made critical evaluations of the endemic Ecuadorean species of Ericaceae in which they followed the IUCN Red List guidelines - it is hoped that formal conservation assessments might soon be carried out for the entire family.

\section{Acknowledgments}

I appreciate the many helpful comments made on drafts by Dra. Carmen Ulloa Ulloa (Missouri Botanical Garden, St. Louis) and one anonymous reviewer. Dr. Edward J. Kennelly (Lehman College, City University of New York, Bronx) provided pdf copies of literature. I thank Dra. Carmen Galdames who prepared figure 1.

Author's Request: As stated several times in the text, there are few actual studies of many of the biological aspects of Ecuadorean Ericaceae-pollination and dispersal systems, chemistry, cytology, mycorrhizae, conservation - and this author would very much appreciate receiving general information of ongoing research in these areas, as well as references to and pdf copies of published papers, or contact information from current researchers (i.e., email addresses). It is also hoped that this review of Ecuadorean Ericaceae will stimulate others to collect more field data and make more observations on pollination and dispersal interactions, as well as other biological phenomena in neotropical Ericaceae.

\section{Literature Cited}

Abril, SF. 2015. Estudio etnobotánico de la comunidad Shiña, provincia del Azuay. Tesis de pregrado. Universidad del Azuay, Cuenca, Ecuador. http://dspace.uazuay.edu.ec/handle/ datos/4847

Acero LE, Bernal HY. 2003. Guía para el cultivo, aprovechamiento y conservación de la uva camarona (Macleania rupestris) (H.B.K.) A.C. Smith. Primera Edición. Editorial Convenio Andrés Bello, España.

Alarcón-Barrera KS, Armijos-Montesinos DS, García-Tenesaca M, Iturralde G, Jaramilo-Vivanco T, Granda-Albuja MG, Giampieri F, \& Alvarez-Suarez JM. 2018. Wild Andean blackberry (Rubus glaucus Benth.) and Andean blueberry (Vaccinium floribundum Kunth) from the highlands of Ecuador: nutritional composition and protective effect on human dermal fibroblasts against cytotoxic oxidative damage. J. Berry Res. 8: 223-236.

Álvarez C, JP, Contreras C, GE. 2012. Síntesis in vitro de micorrizas en Macleania rupestris y Cavendishia bracteata a partir de hongos aislados de raíces y suelo rizosférico. Trabajo de Grado. Universidad Francisco de Paula Santander, Ingeniería Biotecnológica. Cúcuta, Colombia.

Añazco M. 2008. Usos medioambientales de las plantas. Pp.115-119. In: Torre L de la et al., eds. Enciclopedia de las Plantas Útiles del Ecuador. Pontificia Universidad Católica del Ecuador, Quito \& Universidad de Aarhus, Denmark.

Arévalo Maldonado HA. 2014. Caracterización morfológica y del daño de Gracillariidae (Lepidoptera: Gracillariidae) en plantas de importancia económica en Colombia. Unpubl. thesis "Magister en Ciencias Agrarias Entomología." Universidad Nacional de Colombia, Bogotá.

Baker HG. 1974. The evolution of weeds. Ann. Rev. Ecol. Syst. 5: 1-24.

Ballington JR, Luteyn JL, Thompson MM. 1990. Small fruit germplasm resources in the Andean region of Ecuador. North Carolina State Univ. Horticultural Crops Research Series No. 91.

Ballington JR, Luteyn J, Thompson MM, Romoleroux K, Castillo R. 1993. Rubus and vacciniaceous germplasm resources in the Andes of Ecuador. Plant Genetic Resources Newsletter 93: 9-15. 
Beattie AJ, Hughes L. 2002. Ant-plant interactions. Chap. 8, pp. 211-235. In: Herrera CM \& Pellmyr O, eds. Plant-animal interactions: an evolutionary approach. Blackwell Science, Oxford, UK.

Benzing DH. 1987. Vascular epiphytism: taxonomic participation and adaptive diversity. Ann. Missouri Bot. Gard. 74(2): 183-204.

Bermudes D, Benzing DH. 1989. Fungi in neotropical epiphyte roots. BioSystems 23: 65-73.

Blüthgen N, Verhaagh M, Goitía W, Jaffé K, Morawetz W, Barthlott W. 2000. How plants shape the ant community in the Amazonian rainforest canopy: the key role of extrafloral nectaries and Homopteran honeydew. Oecologia 125: 229-240.

Boni Duchitanga SM. 2016. Evaluación de un sustrato orgánico para el enraizamiento de las estacas de joyapa (Macleania rupestris). Tesis previa a la obtención del título de Ingeniera Agrónoma. Universidad de Cuenca, Facultad de Ciencias Agropecuarias Carrera de Ingeniería Agronómica. Cuenca, Ecuador.

Brand-Prada M. 1994. Interacciones entre colibríes y las ericáceas Macleania rupestris y Befaria resinosa en un páramo de Colombia. Pp. 663-677. In: Mora-Osejo LE, Sturm H, eds. Estudios ecológicos del páramo y del bosque altoandino Cordillera Oriental de Colombia. Tomo II. Academia Colombiana de Ciencias, Exactas, Físicas y Naturales, Colección Jorge Álvarez Lleras No 6. Santa Fe de Bogotá, D.C.

Bronstein JL, Alarcón R, Geber M. 2006. The evolution of plant-insect mutualisms. New Phytol. 172: 412-428.

Brundrett MC. 2008-continuous. Mycorrhizal associations: the web resource. https://mycorrhizas. info, ver. 2 .

Brundrett MC, Tedersoo L. 2018. Evolutionary history of mycorrhizal symbioses and global host plant diversity. New Phytol. 220: 1108-1115.

Bussmann RW, Sharon D. 2006. Traditional medicinal plant use in Loja province, southern Ecuador. J. Ethnobiol. Ethnomed. 2: 44.

Cardozo RH, Córdoba SL, González JD, Guzmán JR, Lancheros HO, Mesa LI, Pacheco RA, Pérez BA, Ramos FA, Torres ME, Zúñiga PT. 2009. Uva Camarona Macleania rupestris (Kunth) A.C. Smith. Pp. 81-93. In: Guzmán-Castañeda JR, Córdoba-Cárdenas SL, Zuñiga-Upegüi PT, Torres-Cárcamo ME, Pérez-Martínez BA, Mesa-Castellanos LI, Pacheco-Salamanca RA, Córdoba C, eds. Especies útiles en la Región Andina de Colombia. Tomo 1. Jardín Botánico José Celestino Mutis. Bogotá, Colombia.

Cerón CE. 1993. Etnobotánica del Ecuador: estudios regionales. Hombre y Ambiente Monogr. No. 25. Abya-Yala, Quito.

Cerón CE. 2002a. Etnobotánica del Pondoa, volcán Tungurahua. Cinchonia 3: 26-35.

Cerón CE. 2002b. Etnobotánica del Río Upano, sector Purshi-Zuñac, Parque Nacional Sangay. Cinchonia 3: 36-45.

Cerón CE, Montalvo C, Calazacón A, Toasa G. 2004. Etnobotánica Tsáchila, Pichincha-Ecuador. Cinchonia 5: 109-194.

CESA (Central Ecuatoriana de Servicios Agrícolas). 1992. Usos tradicionales de las especies forestales nativas en el Ecuador, 2 vols. FEPP, Quito.

Chamorro FJ, Nates-Parra G. 2015. Floral and reproductive biology of Vaccinium meridionale 
(Ericaceae) in the Eastern Andes of Colombia. Revta. Biol. Trop. 63: 1197-1212.

Chaves ME, Arango N, eds. 1998. Informe nacional sobre el estado de la biodiversidad 1997: Causas de pérdida de biodiversidad, 3. Instituto Alexander von Humboldt, Programa de las Naciones Unidas para el Medio Ambiente-PNUMA, Ministerio del Medio Ambiente, Bogotá.

Churchill SP, Balslev H, Forero E, Luteyn JL, eds. 1995. Biodiversity and conservation of neotropical montane forests. New York Botanical Garden, Bronx, NY.

Clemants SE. 1995. Bejaria. Pp. 54-106. In: Luteyn JL, ed. Fl. Neotr. Monogr. 66. Ericaceae Part II, the superior-ovaried genera. New York Botanical Garden, Bronx.

Colwell RK. 1973. Competition and coexistence in a simple tropical community. Amer. Naturalist 107: 737-760.

Colwell RK. 1985. Stowaways on the hummingbird express. Nat. Hist. 7/85: 56-63.

Colwell RK. 1995. Effects of nectar consumption by the hummingbird flower mite Proctolaelaps kirmsei on nectar availability in Hamelia patens. Biotropica 27: 206-217.

Colwell RK, Naeem S. 1994. Life history patterns of hummingbird flower mites in relation to host phenology and morphology. Chap. 2, pp. 23-44. In: Houck MA, ed. 1994. Mites: ecological and evolutionary analyses of life history patterns. Chapman \& Hall, New York.

Colwell RK, Betts BJ, Bunnell P, Carpenter FL \& Feinsinger P. 1974. Competition for the nectar of Centropogon valerii by the hummingbird Colibri thalassinus and the flower-piercer Diglossa plumbea, and its evolutionary implications. Condor 76: 447-452.

Cordero L. 1950. Enumeración botánica de las principales plantas, así útiles como nocivas, Indígenas ó aclimatadas, que se dan en las provincias del Azuay y del Cañar de la República del Ecuador. 2nd ed. Afrodisio Aguado S.A., Madrid.

Cornejo X, ed. 2014. Plants of the South American Pacific mangrove swamps: Colombia, Ecuador, Peru). Universidad de Guayaquil y Conservación Internacional (Ecuador), Guayaquil. [Ericaceae, pp. 152-158, plates 21-23].

DAMA. 2000. Protocolo distrital de restauración ecológica: guía para la restauración de ecosistemas nativos en las áreas rurales de Santa Fé de Bogotá. Departamento Técnico Administrativo Medio Ambiente (DAMA), Alcaldía Mayor de Santa Fé de Bogotá, Bachaqueros, Fundación Estación Biológica. Santa Fé de Bogotá.

Dastmalchi K, Flores G, Petrova V, Pedraza-Peñalosa P, Kennelly EJ. 2011. Edible neotropical blueberries: antioxidant and compositional fingerprint analysis. J. Agric. Food Chem. 2011: 30203026.

Debnath SC, Goyali JC. 2020. In vitro propagation and variation of antioxidant properties in micropropagated Vaccinium berry plants—a review. Molecules 25: 788.

Denslow JS, Moermond TC. 1982. The effect of accessibility on rates of fruit removal from tropical shrubs: an experimental study. Oecologia 54: 170-176.

Durán-Casas S, Veloza-Suan C, Magnitskiy S, Lancheros HO. 2013. Evaluation of uva camarona Macleania rupestris (Kunth) A.C. Smith propagation with air layering (Evaluación de la propagación de uva camarona Macleania rupestris (Kunth) A.C. Smith por medio de acodos aéreos). Agron. Colomb. 31: 18-26.

Ellemann L. 1991. El uso de la madera del bosque montano por los Saraguros. Pp. 139-148. In: 
Rios M, Pedersen HB, eds. Las plantas y el hombre. 1 ra Ed. Abya Yala, Quito, Ecuador.

Fadaei S. 2019. Effects of ericoid mycorrhizal fungi on growth and salt tolerance of blueberry (Vaccinium myrtilloides), lingonberry (Vaccinium vitis-idaea), and Labrador tea (Rhododendron groenlandicum): implications for oil sands reclamation. MS degree. University of Alberta, Canada.

Faegri K, van der Pijl L. 1979. The principles of pollination ecology. Third edition. Pergamon Press, Oxford, UK.

Flores G, Dastmalchi K, Dabo AJ, Whalen K, Pedraza-Peñalosa P, Foronjy RF, D'Armiento JM, Kennelly EJ. 2012 Antioxidants of therapeutic relevance in COPD from the neotropical blueberry Anthopterus wardii. Food Chemistry 131: 119-125.

Freitas L, Galetto L, Sazima M. 2006. Pollination by hummingbirds and bees in eight syntopic species and a putative hybrid of Ericaceae in Southeastern Brazil. PI. Syst. Evol. 258(1): 49-61.

Gallardo de la Puente C. 2015. Mortiño: la perla de los Andes. Centro de Investigación, Innovación y Promoción de la Gastronomía Ecuatoriana (CIGE) de la UDLA, Rescate de los Sabores Tradicionales del Ecuador, y Alcaldía de Quito.

Gotsch SG, Nadkarni N, Darby A, Glunk A, Dix M, Davidson K, Dawson TE. 2015. Life in the treetops: ecophysiological strategies of canopy epiphytes in a tropical montane cloud forest. Ecol. Monogr. 85: 393-412.

Gutiérrez B Coba de. 1991. Hongos fitopatogenos encontrados en hojas, flores y frutos de Macleania rupestris (H.B.K.) A.C. Smith. Agron. Colomb. 8: 257-260.

Hamilton LS. 2001. Una campaña por los bosques nublados: ecosistemas únicos y valiosos en peligro. Pp. 41-50. In: Kappelle M, Brown AD, eds. Bosques nublados del Neotrópico. Instituto Nacional de Biodiversidad, INBio, Santo Domingo de Heredia.

Heinrich B. 1976. The foraging specializations of individual bumblebees. Ecol. Monogr. 46: 105128.

Heinrich B. 1981. The energetics of pollination. Ann. Missouri Bot. Gard. 68: 370-378.

Heinrich B. 1983. Insect foraging energetics. Pp. 187-214. In: Jones CE, Little RJ, eds. Handbook of experimental pollination biology. Van Nostrand Reinhold, New York.

Henderson A, Churchill SP, Luteyn JL. 1991. Neotropical plant diversity. Nature 351:21 22.

Hernani-Lineros L, García E, Pacheco LF. 2020. Andean bear diet near to and far from a road. Ursus 2020(31e7): 1-7.

Herrera CM. 2002. Seed dispersal by vertebrates. Pp. 185-208. In: Herrera CM, Pellmyr O, eds. 2002. Plant-animal interactions: an evolutionary approach. Blackwell Science, Oxford, UK.

Hofstede RGM, Groenendijk JP, Coppus R, Fehse JC, Sevink J. 2002. Impact of pine plantations on soils and vegetation in the Ecuadorian high Andes. Mt. Res. Dev. 22(2): 159-167.

Inouye DW. 1980. The terminology of floral larceny. Ecology 61: 1251-1253.

Inouye DW. 1983. The ecology of nectar robbing. Chap. 5, pp. 152-173. In: Bentley BL, Elias TS, eds. The biology of nectaries. Columbia University Press, New York.

Irwin RE, Bronstein JL, Manson JS, Richardson L. 2010. Nectar robbing: ecological and evolutionary perspectives. Ann. Rev. Ecol. Evol. Syst. 41: 271-292. 
Jacquemart A-L. 2003. Floral traits of Belgian Ericaceae species: are they good indicators to assess the breeding systems? Belgian J. Bot. 136: 154-164.

Jeník J. 1971. Root structure and underground biomass in equatorial forests. Pp. 323-337. In: Productivity of forest ecosystems. Proceedings of the Brussels Symposium, UNESCO and IBP, 27-31 October 1969. UNESCO, Paris, France.

Kottke I, Haug I, Setaro S, Suárez JP, Weiß M, Preußing M, Nebel M, Oberwinkler F. 2008. Guilds of mycorrhizal fungi and their relation to trees, ericads, orchids and liverworts in a neotropical mountain rain forest. Basic Appl. Ecol. 9: 13-23.

Kottke I, Setaro S, Haug I, Herrera P, Cruz D, Fries A, Gawlik J, Homeier J, Werner FA, Gerique A, Suárez JP. 2013. Mycorrhiza networks promote biodiversity and stabilize the tropical mountain rain forest ecosystem: perspectives for understanding complex communities. Chapter 14, pp. 187-203. In: Bendix J, Beck E, Brauning A, Makeschin F, Mosandl R, Scheu S, Wilcke W, eds. Ecosystem services, biodiversity and environmental change in a tropical mountain ecosystem of South Ecuador. Ecological Studies 221. Springer-Verlag Berlin Heidelberg.

Kraemer M. 2001. On the pollination of Bejaria resinosa Mutis ex Linné F. (Ericaceae), an ornithophilous Andean páramo shrub. Flora 196: 59-62.

Kron KA, Luteyn JL. 2005. Origins and biogeographic patterns in Ericaceae: new insights from recent phylogenetic analyses. Biol. Skr. 55: 479-500.

Kvist LP, Alarcón S, D. 2008. Plantas tóxicas. Pp. 99-104. In:Torre L de la et al., eds. Enciclopedia de las plantas útiles del Ecuador. Pontificia Universidad Católica del Ecuador, Quito \& Universidad de Aarhus, Denmark.

Laegaard S. 1992. Influence of fire in the grass páramo vegetation of Ecuador. Pp. 151-170. In: Balslev H, Luteyn, JL, eds. Páramo: an Andean ecosystem under human influence. Academic Press, London.

León-Yánez S, Valencia R, Pitman N, Endara L, Ulloa Ulloa C, Navarrete H, eds. 2011. Libro rojo de las plantas endémicas del Ecuador. 2nd ed. Pontificia Universidad Católica del Ecuador, Quito.

Llivisaca S, Manzano P, Ruales J, Flores J, Mendoza J, Peralta J, Cevallos-Cevallos JM. 2018. Chemical, antimicrobial, and molecular characterization of mortiño (Vaccinium floribundum Kunth) fruits and leaves. Food Sci. Nutr. 6: 934-942.

Luteyn JL. 1979. Notes on neotropical Vaccinieae (Ericaceae) VII. Novelties from Ecuador. Brittonia 31: 156-163.

Luteyn JL. 1981. Notes on neotropical Vaccinieae (Ericaceae). IX. Seven new Andean blueberries. Brittonia 33: 371-381.

Luteyn JL. 1983. Part I. Cavendishia. Fl. Neotrop. Monogr. 35: 1-290.

Luteyn JL. 1985. Clave para los géneros de las Ericáceas en el Ecuador. Revista Publ. Mus. Ecuatoriano Cienc. Nat. 4, Año 6: 5-8.

Luteyn JL. (coauthor \& ed.). 1995. Ericaceae, Part II. The superior-ovaried genera (Monotropoideae, Pyroloideae, Rhododendroideae, and Vaccinioideae p.p.). Fl. Neotr. Monogr. 66. [Authors: Luteyn $J L$, Clemants SE, Diggs GM, Dorr LJ, Judd WS. Sørensen PD, Stevens PF, Wallace GD] [Pernettya, pp. 365-383; Gaultheria, pp. 384-488]

Luteyn JL. 1996. Ericaceae. In: Harling G, Andersson L, eds. Fl. Ecuador 54: 1-404, i-viii. Department of Systematic Botany, Goteborg University, Copenhagen. 
Luteyn JL. 1999. Páramos: a checklist of plant diversity, geographical distribution, and botanical literature. Mem. New York Bot. Gard. 84. New York Botanical Garden Press, Bronx, NY.

Luteyn JL. 2002. Diversity, adaptation, and endemism in neotropical Ericaceae: biogeographical patterns in the Vaccinieae. In: Young K, Ulloa Ulloa C, Luteyn JL, Knapp S, coauthors \& eds. Plant evolution and endemism in Andean South America. Bot. Rev. 68: 55-87.

Luteyn JL. 2004. Ericaceae (Heath family). Pp. 140-143. In: Smith N, Mori SA, Henderson A, Stevenson DW, Heald SV, eds. Flowering plants of the Neotropics. Princeton University Press, Princeton, NJ.

Luteyn JL. 2006. Ericaceae de Ecuador. Rapid Color Guide \# 203 versión 1. 7/2006. The Field Museum. [www.fmnh.org/plantguides/]

Luteyn JL, Pedraza-Peñalosa P. 2013. Nomenclature, taxonomy, and conservation of the neotropical genus Sphyrospermum (Ericaceae: Vaccinieae), including five new species for Colombia, Ecuador, and Peru. Phytotaxa 79: 1-29.

Luteyn JL, Pedraza-Peñalosa P. 2021. Ericaceae. In: Acevedo-Rodríguez P, ed. 2015-onwards. Lianas and climbing plants of the Neotropics. https://naturalhistory.si.edu/research/botany/ research/lianas-and-climbing-plants-neotropics

Luteyn JL, Sylva S, DS. 1999. "Murri" (Antioquia Department, Colombia): hotspot for neotropical blueberries (Ericaceae: Vaccinieae). Brittonia 51: 280-302.

Luteyn JL, Wilbur RL. 1977. New genera and species of Ericaceae (Vaccinieae) from Costa Rica and Panama. Brittonia 29: 255-276.

Ma C, Dastmalchi K, Flores G, Wu S-B, Pedraza-Peñalosa P, Long C, Kennelly EJ. 2013. Antioxidant and metabolite profiling of North American and neotropical blueberries using LC-TOF-MS and multivariate analyses. J. Agric. Food Chem. 61: 3548-3559.

Mast RB, Rodríguez-Maecha JV, Mittermeier RA, Mittermeier CG. 1999. Tropical Andes. Pp. 68-85. In: Mittermeier RA, Robles-Gil P, Mittermeier CG, eds. Hotspots: earth's biologically richest and most endangered terrestrial ecoregions. CEMEX S.A., Mexico City.

Melampy MN. 1987. Flowering phenology, pollen flow and fruit production in the Andean shrub Befaria resinosa. Oecologia 73: 293-300.

Middleton DJ. 1989. Taxonomic studies in the genus Gaultheria L. and related genera (Ericaceae). Ph.D. dissertation, University of Aberdeen, Scotland.

Middleton DJ. 1990. Pernettya or Gaultheria? Plantsman 12(3): 167-177.

Middleton DJ. 1991. Ecology, reproductive biology and hybridization in Gaultheria L. Edinburgh J. Bot. 48: 81-89.

Moncayo Loor AS. 2014. Evaluación del potencial inhibidor de las enzimas alfa y beta glucosidasa en algunos frutos nativos del Ecuador. Trabajo de grado. Universidad del Azuay, Cuenca.

Montenegro AL, Vargas O. 2008. Atributos vitales de especies leñosas en bordes de bosque altoandino de la Reserva Forestal de Cogua (Colombia). Revta. Biol. Trop. 56(2): 705-720.

MuñozV. 2004. Determinación de métodos para producción de mortiño (Vaccinium floribundum Kunth), con fines de propagación y producción comercial. Tesis para optar el Título de Ingeniero en Agroempresas, Universidad San Francisco de Quito, Ecuador. 
Naranjo P. 1994. Plantas alimenticias del Ecuador precolombino. Pp. 283-303. In: Rios M, Pedersen HB, eds. Las plantas y el hombre. Ediciones Abya-Yala, Quito.

Naskrecki P, Colwell RK. 1998[1999]. Systematics and host plant affiliations of hummingbird flower mites of the genera Tropicoseius Baker \& Yunker and Rhinoseius Baker \& Yunker (Acari: Mesostigmata: Ascidae). Monogr. Thomas Say Publ. Entomology. Entomological Society of America, Lanham, MD.

Navarro L. 1999. Pollination ecology and effect of nectar removal in Macleania bullata (Ericaceae). Biotropica 31: 618-625.

Navarro, L. 2001. Reproductive biology and effect of nectar robbing on fruit production in Macleania bullata (Ericaceae). Plant Ecology 152: 59-65.

Navarro L, Ayensa G, Guitián P. 2007. Adaptation of floral traits and mating system to pollinator unpredictability: the case of Disterigma stereophyllum (Ericaceae) in southwestern Colombia. PI. Syst. Evol. 266: 165-174.

Navarro L, Guitián P, Ayensa G. 2008. Pollination ecology of Disterigma stereophyllum (Ericaceae) in southwestern Colombia. PI. Biol. 10: 512-518.

Nieto Orellana AV, Silva Alemán CF. 2012. Influencia de la alteración de hábitat en el uso de recursos florísticos por el ensamble de colibríes en bosques altoandinos del sur del Ecuador. Trabajo de Graduación. Universidad del Azuay, Cuenca.

NRC (National Research Council). 1989. Lost crops of the Incas: little known plants of the Andes with promise for worldwide cultivation. National Academy Press, Washington, D.C.

Oblitas Edquén I. 2012. Determinación morfológica del alicón (Macleania rupestris). Trabajo de investigación. Escuela Académico Profesional de Agronomía. Universidad Nacional de Cajamarca, Perú.

Orme CDL, Davies RG, Burgess M, Eigenbrod F, Pickup N, Olson VA, Webster AJ, Ding T, Rasmussen PC, Ridgely RS, Stattersfield AJ, Bennett PM, Blackburn TM, Gaston TM, Owens IPF. 2005. Global hotspots of species richness are not congruent with endemism or threat. Nature 436: 1016-1019.

Ortiz J, Marín-Arroyo M-R, Noriega-Domínguez M-J, Navarro M, Arozarena I. 2013. Color, phenolics, and antioxidant activity of blackberry (Rubus glaucus Benth.), blueberry (Vaccinium floribundum Kunth.), and apple wines from Ecuador. J. Food Sci. 78(7):C985-C993.

Ortiz Melo, CL, Umba Erazo AC. 2010. Dinámica anual de un ensamble de aves frugívoras y su relación con la dispersión de semillas. Chap. 6, pp. 171-192. In: Rosero L, ed. 2010. Estudios ecológicos en el Parque Natural Municipal Ranchería, un aporte para su conservación. UPTCCORPOBOYACÁ. Colección Ivestigación UPTC No. 27. Tunja, Colombia.

Osbahr K, Ortiz Montero JD, Pérez-Torres J. 2007. Amplitud de nicho y selectividad alimentaria del bortugo de páramo (Cuniculus taczanowskii) (Stolzmann 1885) en un bosque andino nublado (Zipacón - Cundinamarca). Revta. U.D.C.A. Actualidad \& Divulgación Científica 19: 105-114.

Parada-Quintero M, Alarcón-Jiménez D, Rosero-Lasprilla L. 2012. Fenología de la floración de especies ornitófilas de estratos bajos en dos hábitats altoandinos del Parque Natural Municipal Ranchería (Paipa-Boyacá-Colombia). Caldasia 34: 139-154.

Pedraza-Peñalosa P. 2010. Disterigma (Ericaceae: Vaccinieae). Fl. Neotr. Monogr. 108. The New York Botanical Garden Press, Bronx. 
Pedraza-Peñalosa P, Valencia R, Montúfar R, Santiana J, Tye A. 2011 Ericaceae. Pp 299-315 In: León-Yánez, S, Valencia R, Pitman N, Endara L, Ulloa Ulloa C, Navarrete H, eds. Libro rojo de las plantas endémicas del Ecuador. 2nd ed. Publicaciones del Herbario QCA, Pontificia Universidad Católica del Ecuador, Quito.

Pels B, Verweij PA. 1992. Burning and grazing in a bunchgrass páramo ecosystem: vegetation dynamics described by a transition model. Pp. 243-264. In: Balslev H, Luteyn JL, eds. Páramo: an Andean ecosystem under human influence. Academic Press, London.

Popenoe W. 1924. Economic fruit-bearing plants of Ecuador. Contrib. U.S. Natl. Herb. 24:101-134.

Prencipe FP, Bruni R, Guerrini A, Rossi D, Benvenuti S, Pellati F. 2014. Metabolite profiling of polyphenols in Vaccinium berries and determination of their chemopreventive properties. J. Pharm. Biomed. Anal. 89: 257-267.

Proctor M, Yeo P. 1973. The pollination of flowers. Collins, London.

Quiroz Dahik C, Marín F, Arias R, Crespo P, Weber M, Palomeque X. 2019. Comparison of natural regeneration in natural grassland and pine plantations across an elevational gradient in the páramo ecosystem of southern Ecuador. Forests 10(745) (27 pp.).

Raven PH. 1972. Why are bird-visited flowers predominantly red? Evolution 26: 674.

Read DJ, Leake JR, Perez-Moreno J. 2004. Mycorrhizal fungi as drivers of ecosystem processes in heathland and boreal forest biomes. Canad. J. Bot. 82: 1243-1263.

Reyna Achi CE. 2012. Evaluación del potencial antioxidante de joyapa (Macleania rupestris), y aplicación en el procesamiento de alimentos. Tesis de pregrado. Universidad del Azuay, Cuenca, Ecuador.

Rios M, Koziol MJ, Pedersen HB, Granda G, eds. 2007. Plantas útiles del Ecuador: aplicaciones, retos y perspectivas [Useful plants of Ecuador: applications, challenges, and perspectives]. Ediciones Abya-Yala, Quito.

Rodríguez J, Peña J. 1984. Flora de los Andes. Impresión Escala, Bogotá.

Romero O, Sánchez Nieves J. 2004 [Abstract]. Hongos asociados a Macleania rupestris (H.B.K) A.C. Smith en los páramos El Granizo y Guasca, Colombia. Acta Biol. Colomb. 9: 128-129.

Rojas-Nossa SV, Sánchez JM, Navarro L. 2016. Nectar robbing: a common phenomenon mainly determined by accessibility constraints, nectar volume and density of energy rewards. Oikos 125: 1044-1055.

Sælemyr ST. 2004. People, park and plant use: perception and use of Andean 'nature' in the southern Ecuadorian Andes. Norsk Geogr. Tidssk. 58: 194-203.

Schreckinger ME, Wang J, Yousef G, Lila MA, Gonzalez de Mejia E. 2010. Antioxidant capacity and in vitro inhibition of adipogenesis and inflammation by phenolic extracts of Vaccinium floribundum and Aristotelia chilensis. J. Agric. Food Chem. 58: 8966-8976.

Schwery O, Onstein RE, Bouchenak-Khelladi Y, Xing Y, Carter RJ, Linder HP. 2015. As old as the mountains: the radiations of the Ericaceae. New Phytol. 207: 355-367.

Selosse M-A, Setaro S, Glatard F, Richard F, Urcelay C, Weiß M. 2007. Sebacinales are common mycorrhizal associates of Ericaceae. New Phytol. 174: 864-878.

Setaro SD, Kron KA. 2011. Neotropical and North American Vaccinioideae (Ericaceae) share their 
mycorrhizal Sebacinales - an indication for concerted migration? PLoS Currents Tree of Life. 2011 Jul 18. Edition 1.

Setaro S, Weiß M, Oberwinkler F, Kottke I. 2006. Sebacinales form ectendomycorrhizas with Cavendishia nobilis, a member of the Andean clade of Ericaceae, in the mountain rain forest of southern Ecuador. New Phytol. 169:355-365.

Setaro S, Suárez JP, Herra P, Cruz D, Kottke I. 2013. Distinct but closely related Sebacinales form mycorrhizae with coexisting Ericaceae and Orchidaceae in a neotropical mountain area. Chapter 5, pp. 81-105. In: Varma A, Kost G, Oelmüller R, eds. Piriformospora indica: Sebacinales and their biotechnological applications. Soil Biol. 33. Springer-Verlag, Berlin and Heidelberg.

Sierra Escobar A, Mora Osejo LE. 1994. Estudio morfológico del sistema radical de plantas del páramo y del bosque altoandino. Pp. 353-405. In: Mora-Osejo LE, Sturm H, eds. Estudios ecológicos del páramo y del bosque altoandino Cordillera Oriental de Colombia. Tomo II. Academia Colombiana de Ciencias, Exactas, Físicas y Naturales, Colección Jorge Álvarez Lleras No 6. Santa Fe de Bogotá, D.C.

Sleumer HO. 1952. Die Arten der Gattung Gaultheria L. in Brasilien. Bot. Jahrb. Syst. 75: 443-450.

Sleumer HO. 1985. Taxonomy of the genus Pernettya Gaud. (Ericaceae). Bot. Jahrb. Syst. 105: 449-480.

Smith AC. 1946. Studies of South American plants, XI: noteworthy species of Hippocrateaceae and Vacciniaceae. J. Arnold Arb. 27: 86-120.

Snow DW. 1971. Evolutionary aspects of fruit-eating by birds. Ibis 113: 194-202.

Stiles FG. 1985. Seasonal patterns and coevolution in the hummingbird-flower community of a Costa Rican subtropical forest. Pp. 757-787. In: Buckley PA, Foster MS, Morton ES, Ridgely RS, Buckley FG, eds. Neotropical ornithology. Ornithol. Monogr. 36. American Ornithologists' Union, Lawrence, KS.

Tene V, Malagón O, Finzi PV, Vidari G, Armijos C, Zaragoza T. 2007. An ethnobotanical survey of medicinal plants used in Loja and Zamora-Chinchipe, Ecuador. J. Ethnopharmacology 111: 63-81.

Torre L de la, Navarrete H, Muriel M, P, Macía MJ, \& Balslev H, eds. 2008. Enciclopedia de las plantas útiles del Ecuador. Pontificia Universidad Católica del Ecuador, Quito \& Universidad de Aarhus, Denmark.

Torres I, Salinas L, Lara C, Castillo-Guevara C. 2008. Antagonists and their effects in a hummingbirdplant interaction: field experiments. Ecoscience 15: 65-72.

Torres WS, Montoya IA, Ligarreto GA. 2009. Aspectos sociales y económicos de la producción de agraz or mortiño (Vaccinium meridionale Swartz). Pp. 113-134. In: Ligarreto M GA, ed. Perspectivas del cultivo de agraz o mortiño (Vaccinium meridionale Swartz) en la zona altoandina colombiana. Primera edición. Universidad Nacional de Colombia, Bogotá.

Traveset A. 1998. Effect of seed passage through vertebrate frugivores' guts on germination: a review. Perspect. PI. Ecol. Evol. Syst. 1: 151-190.

United States Agency for International Development. 2009. Latin America and the Caribbean selected economic and social data. United States Agency for International Development, Bureau for Latin America and the Caribbean. Washington DC.

Valencia R, Pitman N, León-Yánez S, Jørgensen PM, eds. 2000. Libro rojo de las plantas endémicas 
del Ecuador 2000. Herbario QCA, Pontificía Universidad Católica del Ecuador, Quito.

Van den Eynden V, Cueva E. 2008. Las plantas en la alimentación. Pp. 62-66. In: Torre L. de la et al., eds. Enciclopedia de las Plantas Útiles del Ecuador. Pontificia Universidad Católica del Ecuador, Quito \& Universidad de Aarhus, Denmark.

Van der Pijl L. 1972. Principles of dispersal in higher plants. 2nd ed. Springer-Verlag, New York.

Vasco, C, Riihinen K, Ruales J, Kamal-Eldin A. 2009. Chemical composition and phenolic compound profile of mortiño (Vaccinium floribundum Kunth). J. Agric. Food Chem. 57: 8274-8281.

Veloza-Suan C, Durán S, Magnitskiy S, Lancheros H. 2014. Rooting ability of stem cuttings of Macleania rupestris (Kunth) A.C.Sm., a South American fruit species. Intern. J. Fruit Sci. 14: 343-361.

Vohník M, Sadowsky JJ, Kohout P, Lhotáková Z, Nestby R, Kolařík M. 2012. Novel root-fungus symbiosis in Ericaceae: sheathed ericoid mycorrhiza formed by a hitherto undescribed Basidiomycete with affinities to Trechisporales. PLoS ONE 7(6): e39524.

Zotz G, Almeda F, Bautista-Bello AP, Eskov A, Giraldo-Cañas D, Hammel B, Harrison R, Köster N, Krömer T, Lowry PP, Moran RC, Plunkett GM, Weichgrebe L. 2021. Hemiepiphytes revisited. Perspectives in Plant Ecology, Evolution and Systematics.

Zuluaga Bonilla JE, Espinosa Blanco AS. 2005. Las aves como dispersoras de semillas en la sucesión secundaria de un sector quemado del S.F.F. Iguaque, Boyacá. Trabajo de Grado. Universidad Pedagógica y Tecnológica de Colombia, Tunja. 